\title{
A Conceptual Framework to Measure the Innovative Behaviour of Employees and To Automatically Analyze the Affecting Variables
}

\author{
Bharti Pandya., PhD \\ Business Division, Dubai Women's College, Higher Colleges of Technology, Dubai, UAE \\ bhartipandya@hct.ac.ae \\ Kavita Shah.,PhD \\ Business Division, Dubai Women's College, Higher Colleges of Technology, Dubai, UAE \\ kshah@hct.ac.ae
}

\begin{abstract}
The UAE's organizations are driven to achieve the Vision 2021 to become a competitive knowledge economy and one of the key performance indicators is to keep improving the gross innovation index until UAE becomes the most innovative nation by the year 2021. To that effect, the organisations are experiencing an innovation movement and contributing through various innovation initiatives to achieve the national objective. Hence, it becomes quintessential to measure the innovative practices implemented in an organisation and the growth and sustainability of the innovation will be determined by the behaviour (innovative) of the employees.

Research Objectives - The main research objective is to develop a conceptual framework to electronically measure the innovative practices and the innovative behaviour of the employees working in the higher education organisations in UAE.

Methodology - The epistemological belief that the innovative behaviour of employees is contingent on the context of the organizational setting, the constructivist research paradigm has been applied to investigate the research. The primary data has been collected using the interview method and the secondary data is collected through a systematic review of literature extracted from the various database using the keyword search criteria. Thematic analysis and Narrative analysis has been conducted to analyse the data.

Scope of Investigation - The study has been conducted in the context of UAE higher education organisations. The educators working in private organisations (local and international) were interviewed to determine the constructs of innovative behaviour, associated measures, and the affecting variables.

Summary of Findings - The research found that the innovative behaviour is context specific and is dependent on micro and macro variables; the dominating ones being the organizational policies, the degree of employee engagement and the leadership style. The data can be captured through employees recording the new practices or methods or ideas implemented by them on the official portal on pre-set frequency interval and record the variables that prompted them to implement the innovative practice and/or prevented them to implement the innovative practice. The conceptual framework to measure the innovative behaviour and the practical model to analyze the affecting variables will assist policymakers to capitalize on the behavioural promoter variables and take relevant measures to achieve organizational as well as national objectives.
\end{abstract}

Keywords: Innovation, Innovative practice, Innovation measurement, Employee behaviour, Innovation behaviour, Innovation variables

The current issue and full text archive of this journal is available at www.jraspublications.org/index.php/JRAS/issue/archive

Journal of Research in Administrative Sciences (JRAS)

VII(II), 7-13, ISSN: 2664-2433 


\section{Introduction}

The UAE's organizations are driven to achieve the Vision 2021 to become a competitive knowledge economy and one of the key performance indicators is to keep improving the gross innovation index until UAE becomes the most innovative nation by the year 2021. To that effect, the organisations are experiencing an innovation movement and contributing through various innovation initiatives to achieve the national objective. Hence, it becomes quintessential to measure the innovative practices implemented in an organisation and the growth and sustainability of the innovation will be determined by the behaviour (innovative) of the employees. In 2010, the UAE government launched its national agenda, Vision 2021, with four pillars supporting it to become a competitive knowledge economy (Vision 2021, 2018). Total of 12 key performance indicators were defined and improvement in Globa Innovation Index became one of the indicators under 'United in Knowledge' pillar (Innovation portal, 2018). The UAE government developed its own assessment tool called as Abu Dhabi Innovation Index (hereafter, ADII) to measure its innovation input and innovation output. Plethora of initiatives were taken by the government to promote innovation including massive funding, professional development, innovation labs, discussion panels, and conference. Through organizing innovation month and awards, the government encouraged public and private organizations to promote culture of innovation. The UAE government announced its UAE National Innovation Strategy in 2015 and informed individuals and companies operating in Innovation Priority Sectors to focus on innovation.

Education sector plays a significant role as "quality of education system" is considered as a "diffusion capability indicator" by ADII (DED, 2018) and the Global innovation index consider Human Capital \& Research as the key pillar of the innovation. Therefore, measuring the innovation input and innovation output in the Education sector becomes crucial for any government to progress with its economical objectives.

The core function of higher education organizations is teaching and learning. The educators are knowledge workers and can contribute to innovation through creating innovative curriculums, assessments, new knowledge, idea, practice, method, product or process. Simultaneously, educators can enable students and companies with innovative knowledge, skills, and capabilities. This research will investigate the promoter variables and preventer variables affecting the educators to develop and implement innovative practices and suggest a framework through which organisations can measure these behaviours and thereafter generate reports to identify the responsible variables.

\section{Research Framework \\ Research objective and research questions}

The purpose of this research is to develop a conceptual framework to electronically measure the innovative practices and the innovative behaviour of the educators teaching in higher education organisations in UAE. The research also aims to analyse the existing frameworks available and propose a model that organisations can use to automatically analyse the variables (promoters and preventer) affecting the innovation behaviour and take appropriate measures to build its innovative capacity and performance.

For this paper, we have considered the definition of innovative practice provided by Marks-Maran (2015), which is, "“"new ways to teach students in their disciplines" (P.473). Armstrong (2015) clarified that the pedagogical innovation is individual specific and any method, process, or idea implemented for the first time by an educator will be considered as implementation of innovative practice.

The systematic investigation was carried using the following research questions:

1. How does higher education organisations in UAE measure the innovative behaviour of educators?

2 . Which variables promote the innovative behaviour of educators?
3. Which variable prevent the innovative behaviour of educators?

4. How can organisations improve the data collection of innovative behaviour?

5. How can organisations analyse the promoter and preventer variables to drive the innovation?

Our ontological positioning is that the innovation is the foundation of growth and is evident in all settings. And as practitioner (educator) researchers, our reality is based on our epistemological philosophy that to understand the innovation, the behaviour need to be studied with respect to organizational setting and individual context. The innovative behaviour cannot be restricted to the scores of the leaderboard. The deeper understanding necessitates a subjective inquiry and hence we approached this research with constructivist research paradigm (Meyer \& Land, 2006). Curry (1983); Holt-Reynolds (2000); and Moses and Knutsen (2007) posited that constructivist approach assist researchers to find solutions to problems that are caused due to complex situations and environments and also support researchers to develop learning organisations (Barnett, n.d.) and innovative societies (Charungkaittikul \& Henschke, 2014).

\section{Research Methodology}

A systematic inquiry has been conducted using phenomenological approach. According to Creswell (2009), "Phenomenological research is a strategy of inquiry in which the researcher identifies the essence of human experiences about a phenomenon as described by participants. Understanding the lived experiences marks phenomenology as a philosophy as well as a method, and the procedure involves studying a small number of subjects through extensive and prolonged engagement to develop patterns and relationships of meaning (Moustakas, 1994)" (P.14). The research inquiry required educators to share their experiences in detail regarding implementation of innovative practices in their respective organizations. Heidegger (2005) and Vagle (2014) proposed that phenomenological methodology is ideal for social sciences research where the past experiences are important to study to craft future direction.

Semi-structured interview method was used to collect the primary data and the secondary data was collected through a systematic review of the literature extracted using keyword search criteria. The scope of primary data collection was restricted to those higher education organisations that are not funded by government. This may be the limitation of the study but we made this conscious choice due to factors related to ethics clearance, cultural context, and probable bias of government towards the federal organisations with respect to resources and support.

We audio recorded 24 faculty from 8 higher education organizations offering Bachelor and Master programs. The sampling method was self-select method. The invitation to participate was sent to 107 faculty, 49 faculty responded, and 24 faculty submitted acceptance to be interviewed. Fortunately, they evenly represented the Science, Technology, Engineering, and Maths (STEM) program and nonSTEM programs like Business, Education, Arts, and Social sciences. This demarcation was required as UAE government promoted STEM programs (DED, 2018; Dutta, Lanvin, \& WunschVincent, 2017) over non-STEM programs. The participants were informed of the research objective and the interview recording format prior to submitting acceptance to participate. We declared that the participants can withdraw anytime during and postinterview and assured them to keep their identity confidential. They also have been informed about the process we will follow to save, store, and destroy the data.

Thematic analysis was conducted where the audio was transcribed and codes were developed (Braun \& Clarke, 2006). Patterns were identified and categorised into 4 themes and 27 sub-themes. We both transcribed the data individually and grouped the code to derive the themes and sub-themes. The validity was assured through crosslisting and logical discussions finally resulted into four major themes - Financial variables; Organisational variables; Individual variables; and External variables. Inspired by the Social capital 
assessment tool developed by Krishna and Shrader (1999), we grouped first three themes into Micro levels (internal) and last theme as Macro levels (external).

\section{Literature Review}

According to Marks-Maran (2015), Innovation in education is a "process by which teachers select new ways to teach students in their disciplines" (P.473), practice of which is important to teach students with different learning styles (Coates, 2007). Delivering education using smart platforms (García-peñalvo \& Conde, 2015), providing MOOC classes to students from different nationalities and walks of life (Fournier, Kop, \& Durand, 2014), flipping the class (ArnoldGarza, 2014; O'Flaherty \& Phillips, 2015; Unruh, Peters, \& Willis, 2016) are some of the examples of contribution innovation made in pedagogy. This supports our ontological assumption that innovation is necessary for evolution and progress. The educators, in this digital age, need to be innovative to construct an appropriate learning environment, especially when learning has evolved from humanist approach to connectivism approach (Dunaway, 2011; Kop \& Hill, 2008).

Though innovative practice means implementing a new practice, one-time implementation will not help in attaining the national objective of becoming an innovative country. There is a requirement of behaviour modification where the individual develops and implements innovative practice on regular basis (De Spiegelaere, Van Gyes, De Witte, Niesen, \& Van Hootegem, 2014). The innovative behaviour is established when an individual develops and delivers the innovative practice for the benefit of oneself, colleagues, learners, organisations, and international community of practice (Hannah \& Lester, 2009; Pedraza, Mesa, \& Gaviria, 2016). The book written by Peris-Ortiz, Gómez, Merigó-Lindahl, and Rueda-Armengot (2017) shared the cases of worldwide innovative practices and programs were implemented in Universities from Italy, Spain, Brazil, Columbia, Valencia, and many other countries. According to the OECD report, the Canada Educational system measures the innovation in education by counting the increase in a number of external evaluations, class observations, peer discussions, peer evaluation and teachers collaboration (OECD, 2014); which is similar to the higher education organisations measure of innovative practice.

At the government level, the UAE government uses Global innovation index score to measure its progress to improve ranking in Global Innovation Index Report (Dutta et al., 2017; Mohammed, n.d.). The comparison of the economies of OECD countries and Middle east countries reflect that the Arab countries are weak in innovation and higher education area (World economic forum, 2018) and require transformational changes to catch up with developed countries.

The studies related to innovation/innovative practice in education at organizational level, national level, or international level failed to provide the common definition and meaning of innovative practice. The measures adopted by the international organisations like World Bank; OECD; or World economic forum did not provide theoretical framework or a model to measure the innovative practice or behaviour.

Through this research, we have developed a framework to measure the innovation behaviour of employees and to analyse the variables promoting or preventing the innovative behaviour. The framework is developed after thematic analysis, the findings of which are discussed below.

\section{Findings and Discussions}

After coding and grouping the interview transcripts, four major themes were derived. As depicted in table 1, the first theme was related to Financial Variables. Under this theme, 3 sub-themes were derived namely: Adequate funding for the innovation project; Ease in securing grants; and value of reward assigned by an individual after completion of the project. Educators from STEM programs found these sub-variables to be Promoters. Compared to non-STEM programs, the educators in STEM programs experienced receiving adequate funds and process to secure the grants was hastle-free.

The second theme was related to Organisational variables with 8 subthemes inclusive of organizational policies related to innovation, autonomy to educators, defined accountability, leadership style, spirit of team work and community, support from line manager, and knowledge sharing within organisation. While STEM educators found autonomy as the promoter while non STEM educators held leadership style as a preventive force for them to have reduced innovation behaviour.

As shown in Table 2, the third theme evolved was related to individual variables. This theme comprised of soft sub-variables related to affective variables; cognitive variables; and physical variables (Welch, 2011). The sub-variables for this theme were the key words used by educators like commitment, loyalty, trust, engagement, satisfaction, job knowledge, professional development, and alignment of individual objectives with organizational objective. Both STEM and non-STEM educators had comparatively positive experiences and considered these subvariables as promoters, specially the alignment of themselves with their respective jobs and their passion to perform their job.

All the above themes were experienced by the educators at Micro level, within their community of practice and organisation. The last theme, as shown in table 2, was related to Macro level, the influence of external environment on their experiences related to innovative behaviour. Sub-themes under this variable were items like technology, globalization, intellectual property laws, national agenda drive, legal framework, and government funding. Educators from both set of programs found that National Agenda to become the most innovative country and new regulations regarding 10 years of visa for Innovators acted as a promoter and encouraged them to take innovation initiatives.

\section{Conceptual Framework}

The thematic analysis regarding innovative behaviour of faculty, promtove variables, and preventive variables provided basis to develop a conceptual framework to measure the innovative behaviour and manage the innovtive behaviour by using the reports generated on Predictors and Preventors.

As shown in figure 1, a conceptual framework titled Management of Innovation Behaviour Model - A conceptual framework, the employee will initiate an 'Innovation activity' form on portal. The employee personal information will be pulled from the database. Employee will fill in the innovative project description,resources requirements, stakeholders in the project, and the expected outcome of the project. Once submitted, the employee will receive an autogenerated email and pre-defined approvers will also receive an autogenerated email. Once approved, rejected, or pending information; the status will be auto communicated to the employee.

After completition of the project, the employees will fill in the 'Innovator feedback' form comprised of 4 variables (derived after thematic analysis) and 27 items and provide their feedback on 5 point likert scale from highly promoted to highly prevented. Once feedback is submitted, the system will generate two sets of reports. The first report will reflect the innovative behaviour by providing data related to number of innovative projects/practices initiated; expenditure project wise; frequency of innovative projects per department or employee; number of projects approved or rejected; and the cycle time of the project from inception to completion.

The second auto-generated report will analyse the innovator feedback' and depict the variables premoting the innovative behaviour or preventing the innovative behaviour. Both reports will be auto-sent to the concerned positions so that promoters are encouraged and appropriate actions are taken to diminish preventers. 
Table 1: Themes, Subthemes, and Narrations: Analysis for Financial variables and Organisational variables

\begin{tabular}{|c|c|c|c|c|c|c|c|}
\hline \multirow[b]{2}{*}{ Themes } & \multirow[b]{2}{*}{ Sub-themes } & \multicolumn{3}{|r|}{$\begin{array}{c}\text { Promoters } \\
\text { (number of responses) }\end{array}$} & \multicolumn{3}{|r|}{$\begin{array}{c}\text { Preventers } \\
\text { (number of responses) }\end{array}$} \\
\hline & & STEM & $\begin{array}{l}\text { Non } \\
\text { STEM }\end{array}$ & Participants' Narrations & STEM & $\begin{array}{l}\text { Non } \\
\text { STEM }\end{array}$ & Participants' Narrations \\
\hline \multirow{3}{*}{ 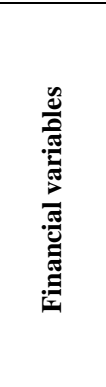 } & $\begin{array}{l}\text { Adequate funding } \\
\text { of the project }\end{array}$ & 7 & 5 & $\begin{array}{l}\text { "Especial departmental budget is given } \\
\text { for the innovative projects" }\end{array}$ & 5 & 7 & $\begin{array}{c}\text { "The total internal funding for organizational innovation is } \\
\text { limited, therefore tight conditions are typically attached to } \\
\text { that" }\end{array}$ \\
\hline & Ease in securing grants & 8 & 4 & $\begin{array}{l}\text { "Online forms are available on portal with guidelines } \\
\text { and FAQ which makes the process easy" } \\
\text { "Specific budgets are mentioned for each types of } \\
\text { activities such as industry visit, learning app } \\
\text { development which ease in planning" } \\
\end{array}$ & 4 & 8 & $\begin{array}{c}\text { "Lots of procedure and approval are required from applying } \\
\text { to till getting things done; for example to call the guest lecture } \\
\text { one has to apply in } 2 \text { months advance which is practically not } \\
\text { feasible sometimes" }\end{array}$ \\
\hline & $\begin{array}{l}\text { Valuable rewards } \\
\text { post-project }\end{array}$ & 6 & 3 & $\begin{array}{l}\text { "I was glad to receive education innovator- } 2017 \\
\quad \text { award with the promotion in the perks" }\end{array}$ & 6 & 9 & $\begin{array}{c}\text { "Organizing the innovative project requires the extra efforts } \\
\text { other than regular job but without monetary benefits , my } \\
\text { team doesn't get motivated" }\end{array}$ \\
\hline \multirow{8}{*}{ 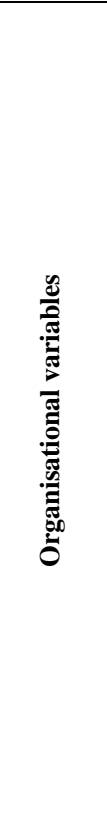 } & Policy & 8 & 4 & $\begin{array}{l}\text { "Separate policies are designed for the innovative } \\
\text { project and line of approval is clearly mentioned." }\end{array}$ & 4 & 8 & $\begin{array}{c}\text { "Policies are not clear, No accountability is mentioned in } \\
\text { rule book" }\end{array}$ \\
\hline & Autonomy & 7 & 9 & $\begin{array}{c}\text { "Empowerment to lead such as freedom of using "out } \\
\text { of the box" learning tools in my class room motivates } \\
\text { me to bring creativity in my job" }\end{array}$ & 5 & 3 & $\begin{array}{l}\text { "My innovative project of "creating the role play" by } \\
\text { students got rejected due to the cultural barrier" }\end{array}$ \\
\hline & Accountability & 5 & 3 & $\begin{array}{l}\text { "Being a curriculum chair, I am responsible for } \\
\text { bringing the innovative tools in the curriculum" }\end{array}$ & 7 & 9 & $\begin{array}{c}\text { "The pressure of being accountable for the success of the } \\
\text { project such as digitalizing courses discouraging me to } \\
\text { participate" }\end{array}$ \\
\hline & Leadership & 6 & 4 & $\begin{array}{c}\text { The long term vision of the top management will } \\
\text { definitely bring in advancement in the classroom such } \\
\text { as virtual learning" }\end{array}$ & 6 & 8 & "The flow of leadership is spoiling the cultural environment" \\
\hline & Team work & 5 & 5 & $\begin{array}{c}\text { We have succeeded in the Inter college app } \\
\text { development competition due to joint efforts", "I can't } \\
\text { think of getting the best department award without my } \\
\text { team" }\end{array}$ & 7 & 7 & $\begin{array}{c}\text { "All colleagues are not like me they don't want to go beyond } \\
\text { miles, so less cooperation" }\end{array}$ \\
\hline & $\begin{array}{l}\text { Support from line } \\
\text { manager }\end{array}$ & 6 & 3 & $\begin{array}{l}\text { "I am blessed with my supervisor who empathize me } \\
\text { in my endeavors" }\end{array}$ & 6 & 9 & $\begin{array}{l}\text { "My boss is not a facilitator, he just goes with book, so my } \\
\text { ideas are with me only" }\end{array}$ \\
\hline & $\begin{array}{l}\text { Collaborative } \\
\text { Community }\end{array}$ & 4 & 7 & $\begin{array}{l}\text { "Selfless efforts of my friend made my classes } \\
\text { possible on Skype during my sick leave" }\end{array}$ & 8 & 5 & $\begin{array}{c}\text { Sometimes when I don't get in return, I take my steps back in } \\
\text { their projects }\end{array}$ \\
\hline & Knowledge sharing & 4 & 8 & $\begin{array}{l}\text { "Employees believe in sharing their project outcome, } \\
\text { one of my colleague shared how to showcase } \\
\text { student's project using social media" }\end{array}$ & 8 & 4 & $\begin{array}{c}\text { "My colleague doesn't like to share their idea due to fear of } \\
\text { competition" }\end{array}$ \\
\hline
\end{tabular}


Table 2: Themes, Subthemes, and Narrations: Analysis for Individual variables and External variables

\begin{tabular}{|c|c|c|c|c|c|c|c|}
\hline \multirow{2}{*}{ Themes } & \multirow[b]{2}{*}{ Sub-themes } & \multicolumn{3}{|r|}{$\begin{array}{c}\text { Promoters } \\
\text { (number of responses) }\end{array}$} & \multicolumn{3}{|r|}{$\begin{array}{c}\text { Preventers } \\
\text { (number of responses) }\end{array}$} \\
\hline & & STEM & $\begin{array}{l}\text { Non } \\
\text { STEM }\end{array}$ & Participants' Narrations & STEM & $\begin{array}{l}\text { Non } \\
\text { STEM }\end{array}$ & Participants' Narrations \\
\hline \multirow{9}{*}{ 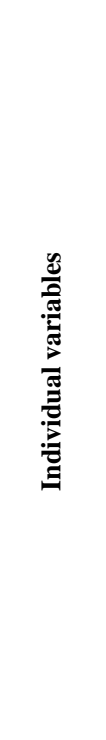 } & Commitment & 8 & 6 & "I feel like I am in the right place to use my creativity" & 4 & 6 & $\begin{array}{l}\text { "I will always look forward for the better opportunity to explore } \\
\text { my knowledge" }\end{array}$ \\
\hline & Passion & 7 & 9 & $\begin{array}{c}\text { "I am passionate towards research work and can put } \\
\text { extra time after job" }\end{array}$ & 5 & 3 & $\begin{array}{l}\text { "I will be more into extra activities such as tutoring, may be after } \\
\text { my 50"s" }\end{array}$ \\
\hline & Loyalty & 8 & 6 & $\begin{array}{c}\text { "I would always like to help my department in reaching } \\
\text { professional goal as they help me achieving my personal } \\
\text { goal" }\end{array}$ & 4 & 6 & "I may change the job for my professional development": \\
\hline & Person-job fit & 8 & 9 & $\begin{array}{c}\text { "I am the best fit for my job but for organizational admin } \\
\text { work, I will rate myself } 2 \text { out of } 4 \text { " }\end{array}$ & 4 & 3 & $\begin{array}{c}\text { "Sometimes, I feel restricting myself only to teaching is not my } \\
\text { cup of tea" }\end{array}$ \\
\hline & Person-organization fit & 5 & 7 & $\begin{array}{l}\text { "I have a long way to go in this organization because my } \\
\text { personal goals are complimenting organizational goal" }\end{array}$ & 7 & 5 & $\begin{array}{c}\text { "I am the best fit for my job but for organizational admin work, I } \\
\text { will rate myself } 2 \text { out of } 4 "\end{array}$ \\
\hline & Job Satisfaction & 7 & 8 & "My students are my first choice" & 5 & 4 & $\begin{array}{c}\text { "I need to occupy myself in something else other than class } \\
\text { room" }\end{array}$ \\
\hline & Engagement level & 7 & 5 & I would love to continue in this culture & 5 & 7 & $\begin{array}{c}\text { "Sometimes, I feel restricting myself only to teaching is not my } \\
\text { cup of tea" }\end{array}$ \\
\hline & $\begin{array}{l}\text { Professional } \\
\text { development }\end{array}$ & 7 & 5 & It's a key for the continuous growth in academics: & 5 & 7 & "More focused trainings are needed in my university" \\
\hline & Job knowledge & 8 & 8 & $\begin{array}{l}\text { "Expectation are transparent to us which ease our } \\
\text { function" }\end{array}$ & 4 & 4 & $\begin{array}{c}\text { The challenge is Expectation towards me are not clear, } \\
\text { performance rating is not detailed" }\end{array}$ \\
\hline \multirow{6}{*}{ 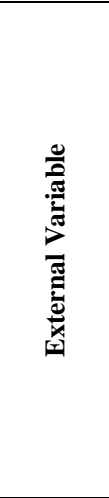 } & Technology & 8 & 7 & $\begin{array}{c}\text { "Technology making a huge contribution in the fast and } \\
\text { ease learning." }\end{array}$ & 4 & 5 & $\begin{array}{c}\text { "Overuse and passion of technology is sometimes shifting the } \\
\text { main academic objective." }\end{array}$ \\
\hline & Globalisation & 8 & 9 & $\begin{array}{c}\text { "Virtual classrooms are the effective way of sharing } \\
\text { knowledge." }\end{array}$ & 4 & 3 & "Globalization making unnecessary expensive." \\
\hline & $\begin{array}{l}\text { Intellectual property } \\
\text { laws }\end{array}$ & 7 & 8 & "Laws are more organized as compare to last decades." & 5 & 4 & "Because of huge market difficult to monitor the copyright." \\
\hline & National Agenda drive & 10 & 6 & "It's a kick start for all organization to go forward." & 2 & 6 & $\begin{array}{c}\text { "National agenda is the big budgeted affair not implemented at } \\
\text { all organizational level" }\end{array}$ \\
\hline & Legal framework & 11 & 9 & $\begin{array}{c}\text { "Organizations are thriving because it is underpinned by } \\
\text { a strong legal framework." }\end{array}$ & 1 & 3 & $\begin{array}{c}\text { "Key principles are not always followed by organization: } \\
\text { simplicity, transparency, fairness and accountability so vice } \\
\text { versa" }\end{array}$ \\
\hline & Government funding & 7 & 10 & $\begin{array}{c}\text { "Prime minister office support to student's project } \\
\text { empowers them to implement the project effectively and } \\
\text { efficiently." }\end{array}$ & 5 & 2 & $\begin{array}{c}\text { "Getting connect to a correct person is the challenge and it may } \\
\text { not be useful on time" }\end{array}$ \\
\hline
\end{tabular}


Figure 1: Management of Innovation Behaviour Model A conceptual framework

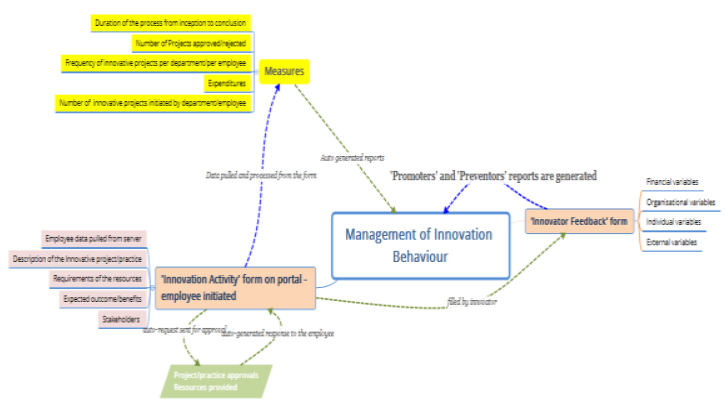

\section{Conclusion, Limitations and Future}

The research paper aimed to develop a conceptual model to measure the innovative behaviour and provide a framework to automatically determine the variables promoting innovation behaviour and preventing innovation behaviour of faculty within higher education organisations of UAE.

The thematic analysis conducted after interviewing 24 faculty concluded that there are 27 sub-variables and 4 main variables affecting the innovation behaviour. The educators have different experiences and these variations are attributed to the program they teach, the financial support they receive, their organizational context, their individual engagement levels, and external factors like government initiatives to promote innovation.

The conceptual framework suggests the organisations to record innovative activities and develop a software or computational program that will generate reports related to the innovation behaviour measures; analyse the innovator feedback data and generate reports related to promoters and preventer to the innovative behaviour of employees.

The model is yet to be empirically tested; the sample size was small and restricted to faculty teaching in UAE; and the concept of the paper can be generalized but as the study is contingent to contextual setting and individual practice, organisations will be required to modify the framework to meet their requirements.

This research study would be useful to the scholars and HR professional who are interested in measuring behaviours. The policy makers at organizational level and national level would derive the value in measuring behaviour that will reflect the continuity of the innovation culture. From 2015 to 2017, UAE had made transformational changes in the government departments, including appointing Chief Innovation Officer in each government organisation (Innovation portal, 2018). The Global Innovation Index ranking also improved from $47^{\text {th }}$ (in 2015) to $35^{\text {th }}$ (in 2017) but dropped by three ranks in 2018 (Dutta, Lanvin, \& Wunsch-Vincent, 2016, 2017, 2018). This reflects that not just innovation, but innovation behaviour needs to be studied extensively. Also it is important to identify, measure, and manage the innovation promoters and innovation preventers.

In future, we plan to test the model and expand the research across various nations, different sectors, and work with programmers to develop a software and a mobile application to facilitate the measurement and management of innovation behaviour.

\section{References}

i. Armstrong, B. (2015). 21st Century Sims : innovation, education, and leadership for the modern era. Annapolis: Naval Institute Press.

ii. Arnold-Garza, S. (2014). The Flipped Classroom Teaching Model and Its Use for Information Literacy Instruction. Communications in Information Literacy, 8(1), 7-22.

iii. Barnett, R. (n.d.). Learning organisations and environments. Retrieved from https://elearning.uol.ohecampus.com iv. Braun, V., \& Clarke, V. (2006). Using thematic analysis in psychology. Qualitative Research in Psychology, 3(2), 77-101. http://dx.doi.org.ezproxy.hct.ac.ae/10.1191/1478088706qp063o

v. Charungkaittikul, S., \& Henschke, J. A. (2014). Strategies for developing a sustainable learning society: An analysis of lifelong learning in Thailand. International Review of Education; Dordrecht, 60(4), 499-522. http://dx.doi.org.ezproxy.hct.ac.ae/10.1007/s11159-014-9444-y

vi. Coates, J. (2007). Generational learning styles. River Falls, Wisconsin: LERN books.

vii. Creswell, J. W. (2009). Research design: qualitative, quantitative, and mixed methods approaches (3rd ed.). Los Angeles: Sage.

viii. Curry, L. (1983). An Organization of Learning Styles Theory and Constructs. Retrieved from http://eric.ed.gov/?id=ED235185

ix. De Spiegelaere, S., Van Gyes, G., De Witte, H., Niesen, W., \& Van Hootegem, G. (2014). On the relation of job insecurity, job autonomy, innovative work behaviour and the mediating effect of work engagement. Creativity and Innovation Management, 23(3), 318-330. https://doi.org/10.1111/caim.12079

x. DED. (2018). The Abu Dhabi innovation index. Abu Dhabi, UAE. Retrieved from https://centres.insead.edu/innovationpolicy/publications/.../En_IndexReport.pdf

xi. Dunaway, M. K. (2011). Connectivism. Reference Services Review, 39(4), 675-685. http://dx.doi.org.ezproxy.hct.ac.ae/10.1108/0090732111118668 6

xii. Dutta, S., Lanvin, B., \& Wunsch-Vincent, S. (2016). Global Innovation Index | Innovation Feeding the World (GII No. 9th). INSEAD. Retrieved from https://www.globalinnovationindex.org/Home

xiii. Dutta, S., Lanvin, B., \& Wunsch-Vincent, S. (2017). Global Innovation Index | Innovation Feeding the World (GII No. 10th). INSEAD. Retrieved from https://www.globalinnovationindex.org/Home

xiv. Dutta, S., Lanvin, B., \& Wunsch-Vincent, S. (2018). Global Innovation Index | Innovation Feeding the World (GII No. 11th). INSEAD. Retrieved from https://www.globalinnovationindex.org/Home

xv. Fournier, H., Kop, R., \& Durand, G. (2014). Challenges to Research in MOOCs. Journal of Online Learning and Teaching; Long Beach, 10(1), n/a.

xvi. García-peñalvo, F. J., \& Conde, M. Á. (2015). The impact of a mobile personal learning environment in different educational contexts. Universal Access in the Information Society, 14(3), 375-387. http://dx.doi.org.ezproxy.hct.ac.ae/10.1007/s10209014-0366-Z

xvii. Hannah, S. T., \& Lester, P. B. (2009). A multilevel approach to building and leading learning organizations. The Leadership Quarterly, 20(1), 34-48. https://doi.org/10.1016/j.leaqua.2008.11.003

xviii. Heidegger, M. (2005). Introduction to phenomenological research. Indiana University Press.

xix. Holt-Reynolds, D. (2000). What does the teacher do?: Constructivist pedagogies and prospective teachers' beliefs about the role of a teacher. Teaching and Teacher Education, 16(1), 2132. https://doi.org/10.1016/S0742-051X(99)00032-3

xx. Innovation - The Official Portal of the UAE Government. (2018). Retrieved September 20, 2018, from https://government.ae/en/about-the-uae/the-uaegovernment/government-of-future/innovation-in-the-uae

xxi. Kop, R., \& Hill, A. (2008). Connectivism: Learning theory of the future or vestige of the past? The International Review of Research in Open and Distributed Learning, 9(3). Retrieved from http://www.irrodl.org/index.php/irrodl/article/view/523

xxii. Krishna, A., \& Shrader, E. (1999). Social capital assessment tool. Presented at the Conference on Social capital and poverty reduction, Washington, DC. Retrieved from 
http://siteresources.worldbank.org/INTSOCIALCAPITAL/Reso urces/Social-Capital-Assessment-Tool--SOCAT-/sciwp22.pdf

xxiii. Marks-Maran, D. (2015). Educational research methods for researching innovations in teaching, learning and assessment: The nursing lecturer as researcher. Nurse Education in Practice; Kidlington, 15(6), 472-479. http://dx.doi.org.ezproxy.hct.ac.ae/10.1016/j.nepr.2015.01.001

xxiv. Meyer, J. H. ., \& Land, R. (2006). Constructivism and Troublesome Knowledge. In Overcoming barriers to student understanding: Threshold concepts and troublesome knowledge (pp. 33-47). London, UK: Routledge.

xxv. Mohammed, S. (n.d.). UAE established innovation as a culture. Retrieved September 17, 2017, from https://sheikhmohammed.ae:443/enus/news/details?nid=24218\&cid=General+News

xxvi. Moses, J., \& Knutsen, T. (2007). Chapter 8: A constructivist philosophy of science. In Ways of knowing: Competing methodologies in social and political research (1st ed.). Basingstoke, UK: Palgrave Macmillan.

xxvii. National Agenda 2021. (2018). Retrieved September 17, 2018 , from https://www.vision2021.ae/en/national-agenda-2021

xxviii. OECD. (2014). Measuring innovation in education: A new perspective, educational research and innovation. OECD Publishing. http://dx.doi.org/10.1787/9789264215696-en

xxix. O'Flaherty, J., \& Phillips, C. (2015). The use of flipped classrooms in higher education: A scoping review. The Internet and Higher Education, 25, 85-95. https://doi.org/10.1016/j.iheduc.2015.02.002

xxx. Pedraza, C. G., Mesa, F. B., \& Gaviria, M. (2016). Innovative Behaviour and Employee Engagement: A Case Study in a Family Business. In European Conference on Innovation and Entrepreneurship; Reading (pp. 1013-1016). Reading, United Kingdom, Reading: Academic Conferences International Limited. Retrieved from https://search-proquestcom.ezproxy.hct.ac.ae/docview/1860070195/abstract/4D4F5E0 55A024D60PQ/1

xxxi. Peris-Ortiz, M., Gómez, J. A., Merigó-Lindahl, J., \& RuedaArmengot, C. (2017). Entrepreneurial universities: exploring the academic and innovative dimensions of entrepreneurship in higher education. Cham, Switzerland: Springer. Retrieved from http://hct.summon.serialssolutions.com/2.0.0/link/0/eLvHCXM wdVw9C8IwED1EB938qPhRxT9QielHmlWpOgkWF6eSxCtO LuL_9xKtiuiYEI4kPPLuXu4OIORzFny9CYzWLrhYoC61Som FsExi21qcJZqjObkP3jDf8H0e7d7yRyW8nY1L51D4ki6sZxzamnyiCy818f4La240FzaSg4CmG2hnvJHr53XOCIqIaMfVLJuQ 92WF3SghpcuNKu64GsP_OyjxSShYnarciYomPXAX2eH1TY gc8VTcimq7aW8D3UK43EAM61UwoQ8UUxiooQLjToWDE uhhRFayiF4P02M_syPocUtxTg5wIdGSXDFiTvW1N3HHSNf $\mathrm{ZOw}$

xxxii. Unruh, T., Peters, M. L., \& Willis, J. (2016). Flip This Classroom: A Comparative Study. Computers in the Schools, 33(1), 38-58. https://doi.org/10.1080/07380569.2016.1139988

xxxiii. Vagle, M. D. (2014). Crafting phenomenological research. New York: Routledge. https://doi.org/10.4324/9781315431451

xxxiv. Welch, M. (2011). The evolution of the employee engagement concept: communication implications. Corporate Communications: An International Journal, 16(4), 328-346. https://doi.org/10.1108/13563281111186968

xxxv. World economic forum. (2018). The arab world competitiveness report 2018, 1-126. 